\title{
Efficiency of Two Predatory Mites Amblyseius swirskii and Cheletogenes ornatus Early Release in Controlling the Two Spotted Spider Mite, Tetranychus urticae Koch on Soybean Plants in Sharkia Governorate. Amira E. Mesbah \\ Plant Protection Research Institute, A.R.C., Dokki, Egypt
}

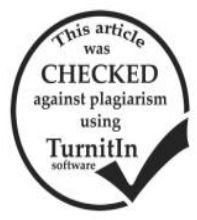

\section{ABSTRACT}

The two predatory mites, Amblyseius swirskii Athias-Henriot and Cheletogenes ornatus Canestrini \& Fanzago were evaluated as early release to control Tetranychus urticae (Koch) on Soybean plants in Sharkia governorate during the period from 15th June to 7th September 2016. Three release levels (2, 4 and 6 predators/leaf) were conducted when population of spider mite was 1-3 individual/leaf. There was no significant difference between the efficiency of the two predators all over the experiment. Reduction percentages were recorded as 54.3, 69.7 and $78.9 \%$ for $A$. swirskii while it was $48.7,61.8$ and $69 \%$ for C.ornatus at three rates of release, respectively. Efficiency increased significantly with predator release rate increase. There was no significant differences between the reduction percentages of 4 and 6 predators/plant. Starting release at low level of infestation to have good control in very short time after releasing is amust.

Keywords :Early release, Amblyseius swirskii, Cheletogenes ornatus, Tetranychus urticae, Soybean

\section{INTRODUCTION}

Soybean, Glycin max L. considered one of the most important field crops in Sharkia Governorate. The two spotted spider mite, Tetranychus urticae Koch is aphytophagous pest that can cause significant yield losses in many agricultural crops, Van Leeuwen et al., 2007.

Spider mites have developed resistance to most available pesticides. Due to the excessive use of pesticides and the associated problems of resistance and environmental pollution. There is an increasing demand for sustainable, environmentally friendly control methods. Acaricides sometimes failed to keep the number of spider mites below economic threshold levels (Tirello et al .,2012).Such dynamics may cause an increase in production costs and a decrease in final product quality due to the presence of toxic residues in the grains (Melgarejo et al. 2013). So that ,ecological management technologies, such as biological control have been played an important role as an alternative strategy in pest management without application of more pesticides (Nicholls and Altieri 2005).Many predaceous mites are now used as biological control agents and are important in IPM programs. Amblyseius swirskii Athias-Henriot is one of the most important generalist indigenous predator of tetranychid mites (Abo-Taka et al., 2014).

Cheletogenes ornatus (C.\&F.) considered a predator of phytophagous mite, Tetranynychus urticae Koch ( Zaher et al., 1981; Moraes et al. 1989; Mesbah,2014 and Hassan et al .,2014).

It is well known that members of the family Cheyletidae Leach show a considerable variation in their feeding habits, including acarid as well as, tetranychid and tenuipalpid mites, in addition to scale insects (Carrillo et al., 2012).

Some researchers thought that its slow predators but experiments indicates well the main role of Cheyletid mites in biological control programs. The feeding method of Cheyletid mites was assessed as well, because Cheyletids are known to both actively search for prey as well as use an ambush method (Hoy 2013 and Mesbah and Omar 2014).

Its the first time of releasing Cheyletid mites in fields. The present study aimed to control the phytophagous mite, Tetranychus urticae Koch on soybean plants by using the two predatory mite species, A. swirskii and $C$. ornatus as well as to evaluate the efficiency of the two predatory mites $A$. swirskii and $C$. ornatus in controlling the spider mite, T. urticae Koch.

\section{MATERIALS AND METHODS}

Field Experiment: The field trials were carried out at Diarb-Nigm district, Sharkia governorate. Soybean plants were planted in mid-May under field condition in summer 2016. An area of about $420 \mathrm{~m}^{2}(10 \times 42 \mathrm{~m})$ was divided into seven plots, (three levels for each predator and one control) each one was $60 \mathrm{~m}^{2}(10 \mathrm{~m} \times 6$ rows $)$. Every plot consisted of six rows $50 \mathrm{~cm}$ apart $(\mathrm{m}=5$ hells). Seeds were shown at a rate of two seeds/hill and $25 \mathrm{~cm}$ space between every two hills. The experiments comprised six treatments, to evaluate three levels of the two predatory mites 2,4 and 6 predators/leaf were compared with untreated control. Polyethylene plastic mulch sheets were placed between different treatments to prevent predator mite from dispersal.

\section{Rearing of mites:}

The rearing and reproduction of each predators and its prey were carried out at Acarology laboratory of Plant Protection Research institute-Sharkia-Egypt

\section{1-Culture of Cheyletid mites:-}

Cheletogenes ornatus observed in high numbers associated with phytophagous mites and scale insects infestation in leaves of date palm, phoenix dactylifera $\mathrm{L}$. (Mesbah,2014) and predators transferred for rearing on immatures of acarid mite during the period of study.

Rearing and reproduction of Acarid mite, Tyrophagus putrescentiae (Schrank), reproduced on yeast granules and incubated at $25^{\circ} \mathrm{c}$ and $70 \pm 5 \%$ relative humidity on big cages filled with a layer of mixture of (Cement: Clay: Charcoal) with percent of (6:3:1) filled on the bottom of cages to depth of $0.5 \mathrm{~cm}$. Water drops was added when needed. The bottom of cages was scratched by using a needle to make convexo-concaved areas used as shelters, photographed by video-camera and was suitable sites for predator mite rearing and laying eggs (Zaher et al. 1981).

\section{2-Culture of Phytoseiid mites:-}

The predator mite, Amblyseius swirskii was collected from soybean plant leaves at Diarb Nigm, Sharkia governorate, Egypt. 
Stock colony of Tetranychus urticae:-T. urticae was maintained on Mulberry leaves in laboratory. Pure culture was initiated by transferring males and females of mite species using a fine hair brush to fresh discs of Mulberry leaves in Petri dishes (10 $\mathrm{cm}$ in diameter). Each leaf was put on apad of cotton saturated with water as a source of moisture and to prevent mite escaping. The rearing stocks were conducted in an incubator under $25 \pm 2^{\circ} \mathrm{C}$ and $70 \pm 5 \%$ relative humidity. After that the bean plant (Phaseoulus vulgaris L.) used as host plant. Bean seeds were planted in plastic trays $(40 \times 40 \times 12 \mathrm{~cm})$ with the rate of 20 seeds per trays. The rearing stocks were conducted in an incubator under $25 \pm 2^{\circ} \mathrm{C}$ and $70 \pm 5 \%$ relative humidity. These trays were used in rearing the predator mite, A. swirskii, which used as nucleation of the predator for releasing in field. About one month when the rate of predator increased to reach 20-30 individuals/ leaflet. The predatory mite was picked in small paper bags with few prey on bean leaves and transferred inside ice box to the place of experiment(Ibrahim et al. 2010).

Early release of Phytoseiid mite, Amblyseius swirskii and Cheyletid mite, Cheletogenes ornatus: The two predatory mites were early released when population of $T$. urticae was 1-3 individual/leaf of Soybean. At rate of 2, 4 and 6 individuals/ leaf.

Sampling: After 30 days post plantation, Random leaf samples of 40 leaves were collected then repeated every seven days from each treatment and examined using stereomicroscope. First samples collected just before release in 15 June for pre-count after releasing and the next collected every seven days from the period of (22 June 2016 to 7 September 2016) . Motile stages of $T$. urticae and two predatory mites, A.swirskii and $C$. ornatus per 40 leaves on lower and upper surface of leaves were counted for each treatment to the end of experiment and the reduction percentages were calculated according to equation of Henderson and Tilton (1955).

Data were analyzed by one-way analysis of variance (ANOVA) and mean comparison using LSD to test the significant differences between mean values and correlation coefficient between mite population and weather factors using SAS statistical software, SAS Institute (2010).

\section{RESULTS AND DISCUSSION}

\section{1-Biological control of Tetranychus urticae Koch using the predatory mite Amblyseius swirskii Athias-Henriot on Soybean 2016:-}

Results in Table (1) indicated that, the predatory mite A. swirskii was early released against the twospotted spider mite $T$. urticae under three levels of $2 ; 4$ and 6 predators/ plant.

First level of release (2predator/ leaf)

The first release of $A$. swirskii was at population density of pre-count were 73 and 100 individuals/ 40 leaves in the release and control, respectively.

A. swirskii gave $(9.1 ; 23 ; 32.9 ; 41.4 ; 60.1 ; 65.8$ ;72 and $73.2 \%)$ reduction percentage in (22nd June ; 29th June ; 6th July ; 13th July ; 20th July ;27th July ;3rd August and10rd August ) at number of the predatory mites of $(7 ; 13 ; 16 ; 15 ; 19 ; 22 ; 30$ and 36$)$ individuals/ 40 leaves, respectively and decreased in the count of $17 \mathrm{rd}$ August to $70.5 \%$ till reach $67.7 \%$ in the count of 7 th September. The highest reduction of $T$. urticae observed in 10rd August was $73.2 \%$ at maximum and minimum temperature of 35.4 and $25.9^{\circ} \mathrm{C}$ and relative humidity $56.4 \%$. The reduction percentages averaged $54.3 \%$ in the end of experiment

\section{Second level of release ( 4 predator/ leaves)}

The second release of $A$. swirskii was at population density of mite pest 85 and number of mites in control were 100 individuals/ 40 leaves. The percent of reduction increased gradually reaching its highest $85.6 \%$ in 31 rd August at maximum and minimum temperature of 34.1 and $24.4{ }^{\circ} \mathrm{C}$ and relative humidity was $59.3 \%$. The reduction percentages averaged $(69.7 \%)$ in the end of experiment.

\section{Third level of release ( 6 predator/ leaves)}

The third release of the predatory mite was at population density of 94 in the release and number of mites in control were 100 (individuals/ 40 leaves). The highest percent of reduction (92.9\%) in 3rd August at maximum and minimum temperature of 35.3 and $25.4^{\circ} \mathrm{C}$ and relative humidity was $58 \%$. The reduction percentage averaged $(78.9 \%)$ in the end of experiment.

2-Evaluating the efficiency of different levels of early release of predatory mite, $A$. swirskii against $\boldsymbol{T}$. urticae on Soybean:- Table(1) showed that the mean percent of reduction in releasing predator $A$. swirskii were $(54.3 ; 69.7$ and 78.9$) \%$ at average number of predator were $(18.5 ; 24.6$ and 28.5$)$ individuals at levels of release $2 ; 4$ and 6 predator/leaf. There were significnt differences between the three levels $(2 ; 4$ and 6 predators). The most efficient level of release was 6 predators per soybean plant to control T.urticae on leaves as it produced the highest reduction percentages recording $78.9 \%$.

Statistical analysis indicated that there was high significant positive correlation between $A$. swirskii populations and minimum temperature $0.86^{* *}$ while there was negative non significant correlation between A. swirskii and maximum temperature (-0.10). However, there was positive non significant correlation between A. swirskii and relative humidity 0.35 .

Phytoseiid mites of the genus Amblysieus have been commonly observed on soybean crops (Reichert et al., 2014; Rezende et al., 2014) and demonstrated capacity to control T. urticae population (Moraes et al., 1989. Oatman et al., 1977) released of Amblyseius californicus on the Two spotted Spider Mite on Strawberry. El-Banna, et al. (2014) noticed the potential of predatory mite, Amblyseius hutu (Pritchard\& Baker) as a biological control agent for tetranychid mite , Oligonychus afrasiaticus (McGregor) which attack date palm trees. Many successful trails have been applied using different phytoseiid predators as abio-control agents against different tetranychid mite pests infesting different crops (El-Saiedy 2003, Ibrahim et al. 2005 and El- Mahgoob 2006). 
Table 1. Reduction percentages of Tetranychus urticae Koch infesting Soybean plants as influenced by early releasing of predatory mite Amblyseius swirskii under field conditions.

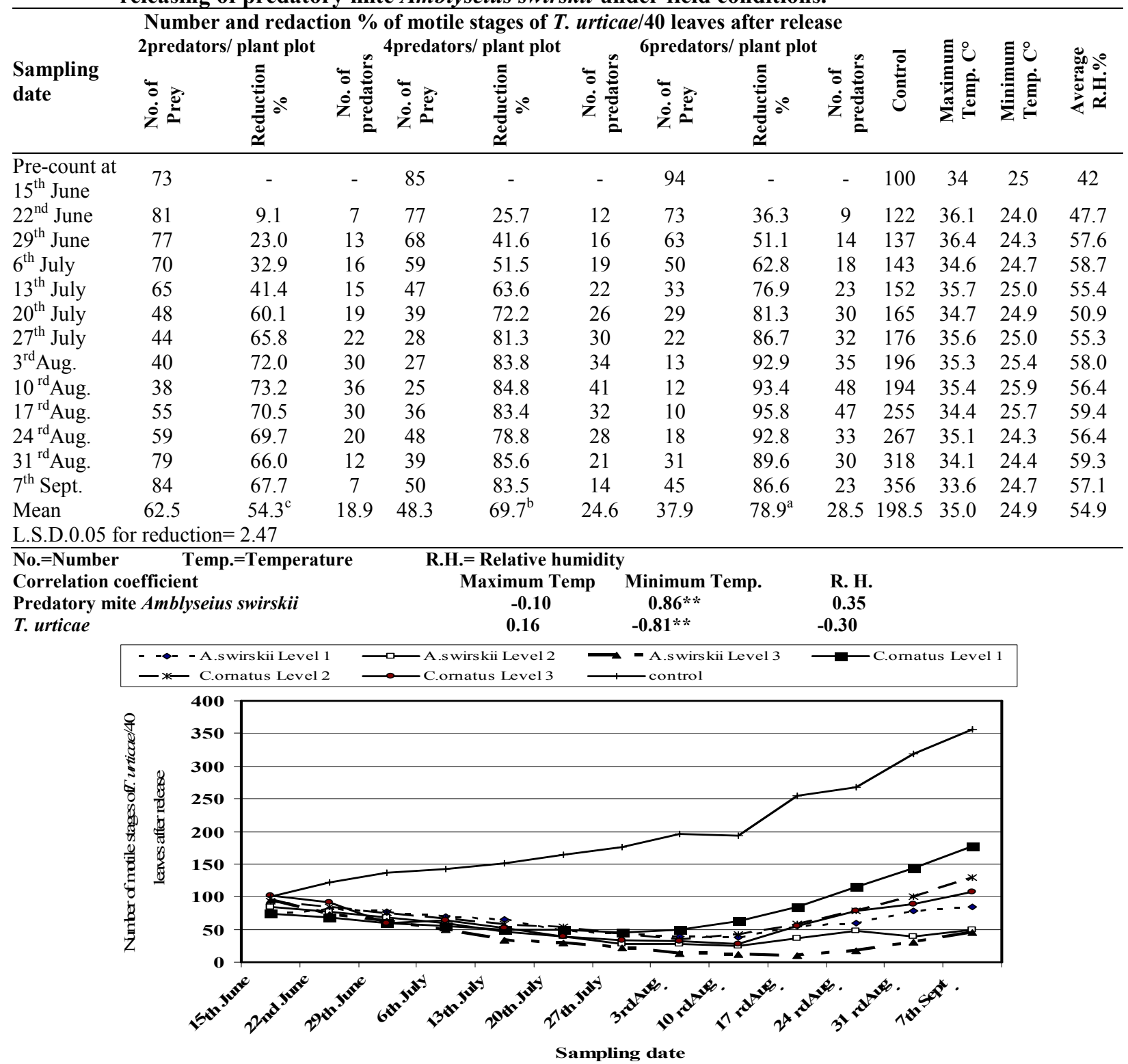

Fig. (1) Number of $T$. urticae infesting Soybean crops after releasing two predatory mites $A$. swirskii and $C$. ornatus under field conditions.

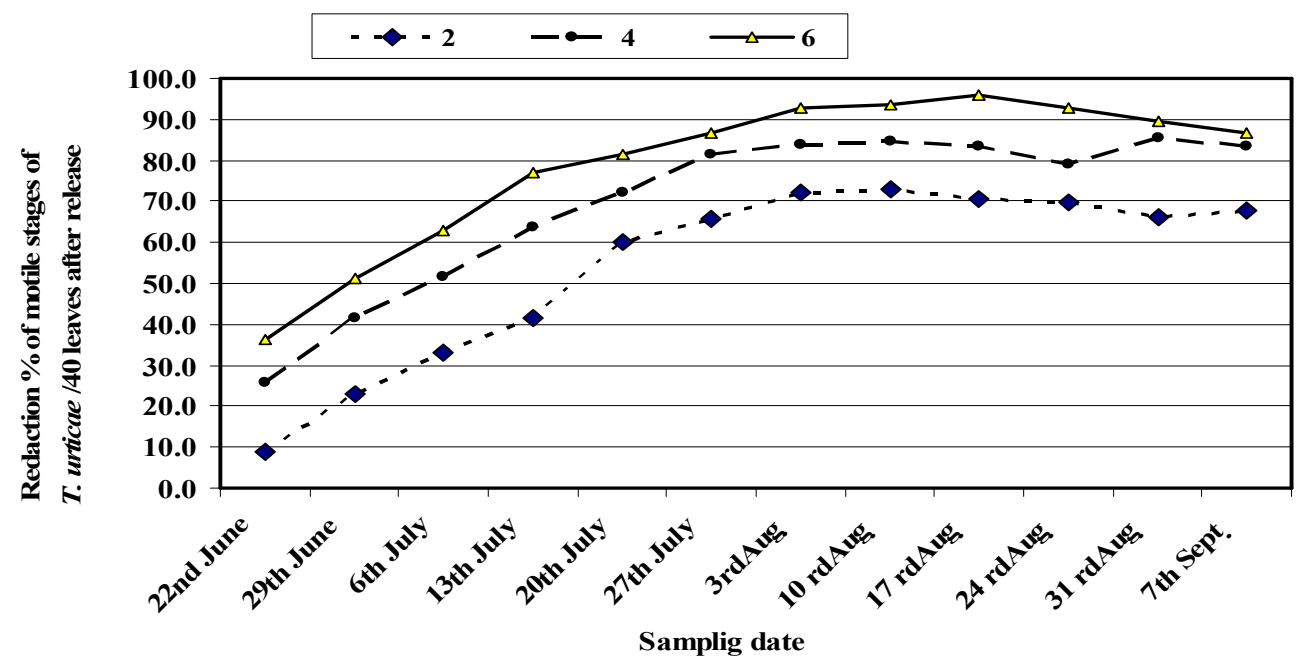

Fig. (2) Reduction percentage of $T$. urticae infesting Soybean crops as influenced by releasing of the predatory mites $A$. swirskii under field conditions. 


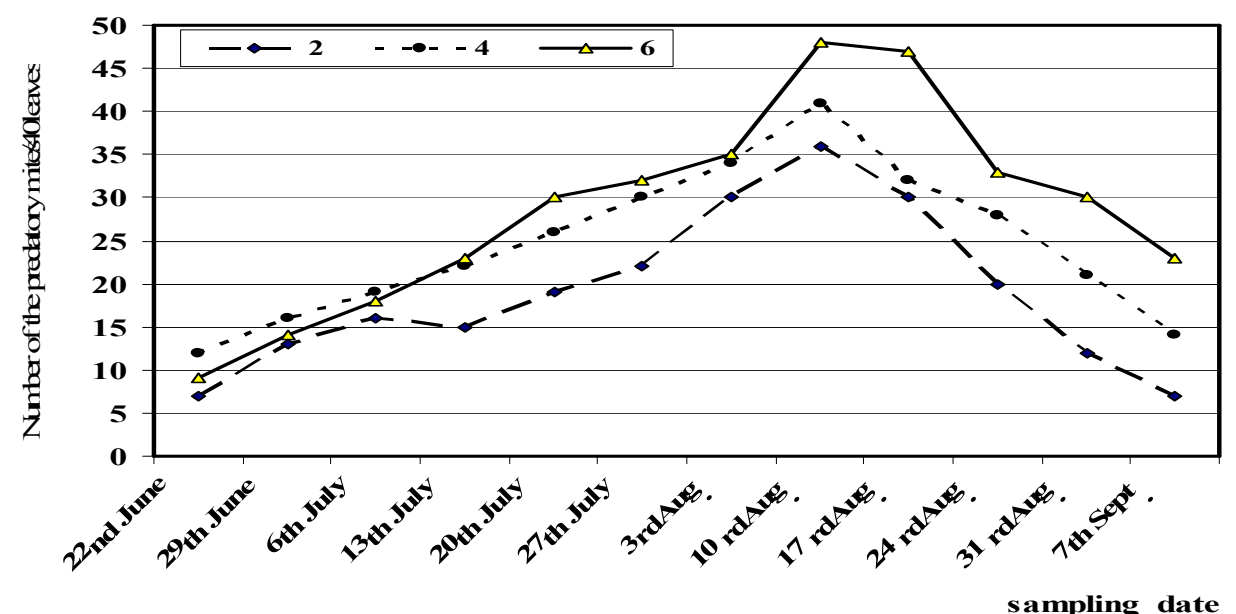

Fig. (3) Number of the predatory mites $A$. swirskii after re leas e on $T$. urticae under field conditions.

The obtained results were in harmony with those obtained by Mowafi (2005) the reduction percentage of early release Phytoseiulus macropils Banks to control T. urticae reached $63 \%$ on cucumber. Abd Elaziz (2016) released Phytoseiulus persimilis Athias-Henriot by rates $(2,4,6$ predator / plant plot) successively reduced the population density of $T$. urticae on eggplant in Sohag governorate and 6 predator/plant enhanced the highest reduction rate 90.44 and $91.47 \%$ in both seasons, respectively. Waheeb (2016) released $N$. californicus at 1:10 level represents auseful management strategy of $T$. urticae Koch on both soybean and cotton plants. El-Moghazy et al.(2012) they released the two phytoseiid mites, N. californicus (McGregor) and Typhlodromips swirskii Athias-Henriot as control agents to T. urticae Koch on two cultivars of faba bean, Vicia faba L. in open field and after releasing the reduction percentage of two spotted mite at prey predator ratio of 1:7 was achieved and N.californicus gave the highest reduction percentage than T.swirskii.

3-Biological control of $\boldsymbol{T}$. urticae using the predatory mite, $C$. ornatus on Soybean plants:-

Results in Table (1) indicated that, the predatory mite $C$. ornatus was early released against the twospotted spider mite $T$. urticae under three levels of $2 ; 4$ and 6 predators/ leaf.

Table 2. Reduction percentages of $T$. urticae infesting Soybean influenced by early releasing of predatory mite, $C$. ornatus under field conditions.

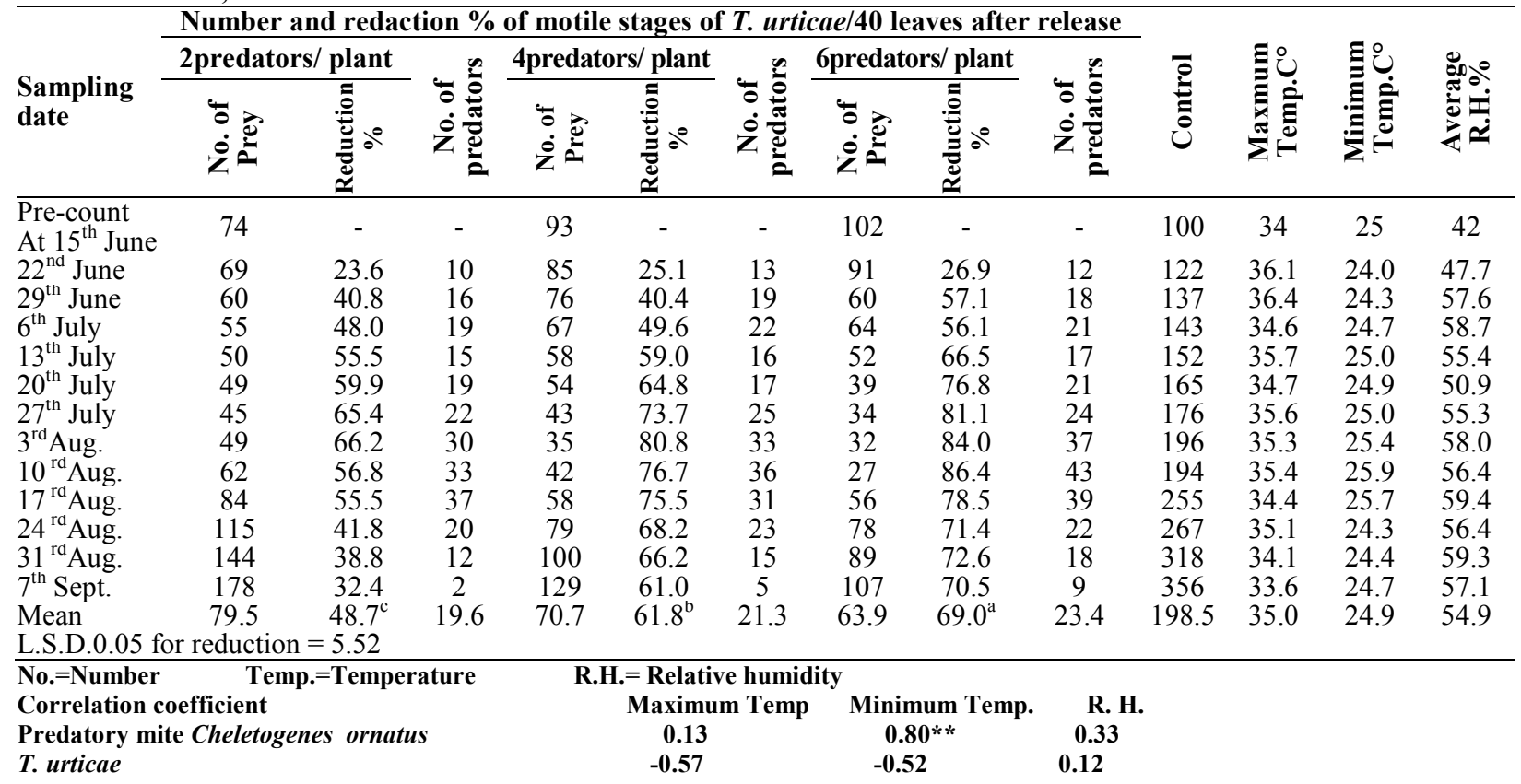

\section{First level of release (2predator/leaves)}

The first release of the predatory mite, C. ornatus was at population density of 74 and 100 individuals/ 40 leaf in the release and control, respectively. C. ornatus gave $(23.6 ; 40.8 ; 48 ; 55.5 ; 59.9 ; 65.4$ and $66.2 \%)$ reduction pest population in $\left(22^{\text {nd }}\right.$ June $; 29^{\text {th }}$ June $; 6^{\text {th }}$
July $; 13^{\text {th }}$ July $; 20^{\text {th }}$ July $; 27^{\text {th }}$ July and $3^{\text {rd }}$ August $)$ at number of the predatory mite $(10 ; 16 ; 19 ; 15 ; 19 ; 22$ and 30) individuals/ 40 leaf, respectively. The highest reduction of $T$. urticae observed $66.2 \%$ in $3^{\text {rd }}$ August at maximum and minimum temperature of 35.3 and 25.4 ${ }^{\circ} \mathrm{C}$ and relative humidity was $58 \%$ and decreased in the 
count of $10^{\text {rd }}$ August to $56.8 \%$ till reach $32.4 \%$ in $7^{\text {th }}$ September. The reduction percentage averaged $48.7 \%$ in the end of experiment at level 2predator/ leaf of release. Second level of release ( 4 predator/leaves)

The second release of $C$. ornatus was at population density of mite pest 93 and number of mites in control were 100 (individuals/ 40 leaves) in the release and control, respectively. The percent reduction of the mite pest increased gradually reaching its highest percent reduction $(80.8 \%)$ in $3^{\text {rd }}$ August at maximum and minimum temperature of 35.3 and $25.4{ }^{\circ} \mathrm{C}$ and $58 \%$ relative humidity. The reduction percentage averaged $61.8 \%$ in the end of experiment.

Third level of release ( 6 predator/leaves)

The third release of $C$. ornatus was at population density of 102 in the release and number of mites in control were 100 (individuals/ 40 leaf).The highest percent of reduction (86.4\%) in 10rd August at maximum and minimum temperature of 35.4 and 25.9 ${ }^{\circ} \mathrm{C}$ and relative humidity was $56.4 \%$. The reduction percentage averaged $69 \%$ in the end of experiment.

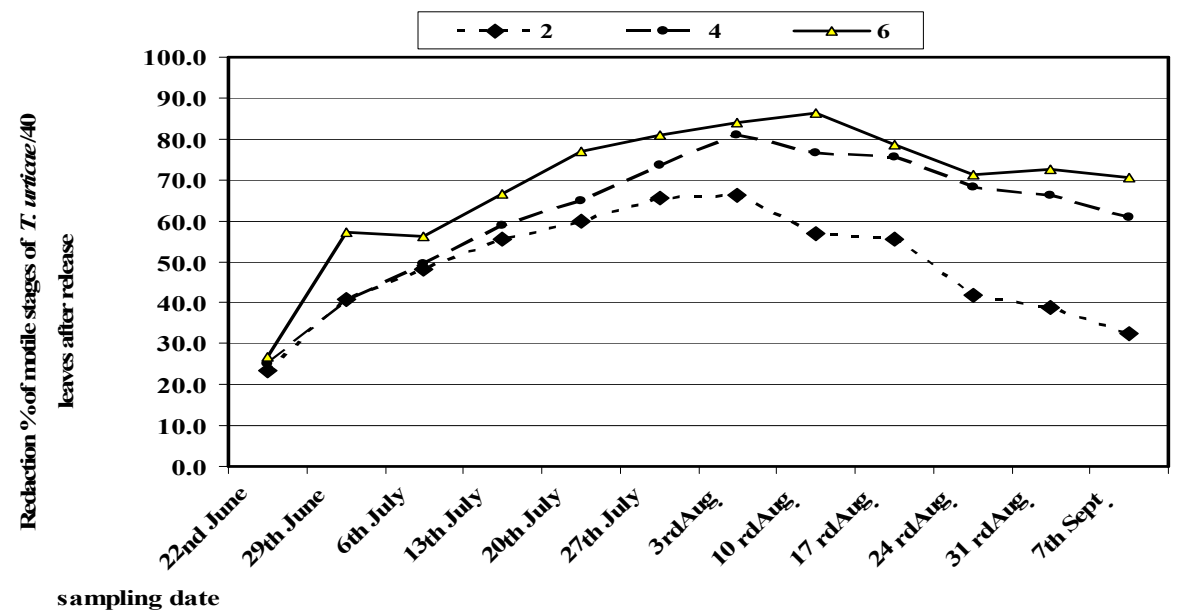

Fig. (4) Reduction percentage of $T$. urticae infesting Soybean crops as influenced by releasing of the predatory mites $C$. ornatus under field conditions.

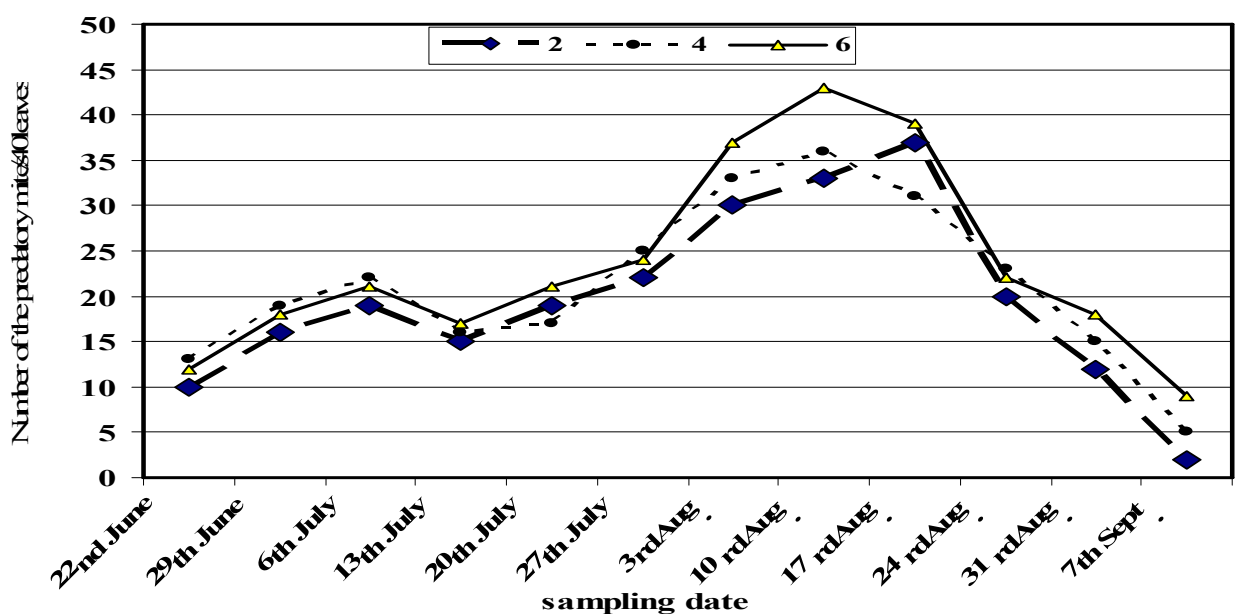

Fig. (5) Number of the predatory mites $C$. ornatus after release on T. urticae under field conditions.

Table 3. The mean reduction of Tetranychus urticae Koch as a result of early releasing of two predatory mites Amblyseius swirskii and Cheletogenes ornatus.

\begin{tabular}{|c|c|c|c|c|}
\hline Predator & $\begin{array}{l}\text { Rate of } \\
\text { release }\end{array}$ & $\begin{array}{c}T . \\
\text { urticae }\end{array}$ & $\begin{array}{c}\text { Reductio } \\
\%\end{array}$ & $\begin{array}{l}\text { Number of } \\
\text { predators }\end{array}$ \\
\hline \multicolumn{3}{|c|}{ Amblyseius swirskii2predators/ plant62.54 bcd } & $54.28^{\mathrm{d}}$ & $18.91^{\mathrm{d}}$ \\
\hline \multicolumn{3}{|c|}{ 4predators/ plant $48.31^{\text {cd }}$} & $69.65^{\mathrm{b}}$ & $24.58^{\mathrm{b}}$ \\
\hline \multicolumn{3}{|c|}{6 predators/ plant $37.92^{\mathrm{d}}$} & $78.85^{\mathrm{a}}$ & $28.5^{\mathrm{a}}$ \\
\hline \multirow[t]{4}{*}{ Cheletogenes } & ornatus 2 predators $/ \mathrm{p}$ & $\mathrm{t} 79.54^{\mathrm{b}}$ & $48.72^{\mathrm{d}}$ & $19.58^{\mathrm{d}}$ \\
\hline & 4predators/ $\mathrm{p}$ & $\mathrm{t} 70.69^{\mathrm{bc}}$ & $61.75^{\mathrm{c}}$ & $21.25^{\mathrm{cd}}$ \\
\hline & 6 predators/ $\mathrm{p}$ & t $63.92^{\mathrm{bc}}$ & $68.92^{\mathrm{b}}$ & $23.41^{\mathrm{bc}}$ \\
\hline & Control & $198.54^{\mathrm{a}}$ & - & - \\
\hline \multicolumn{2}{|l|}{ F. value } & 34.77 & 28.15 & 13.23 \\
\hline \multicolumn{2}{|l|}{ P. } & 0.0001 & 0.0001 & 0.0001 \\
\hline \multicolumn{2}{|l|}{ L.S.D. 0.05} & 25.80 & 5.59 & 2.78 \\
\hline
\end{tabular}

4-Evaluating the efficiency of different levels of early release, $C$. ornatus (C \&F) against $T$. urticae Koch on Soybean:- Obtained data recorded in, Table(1) showed that the mean reduction percentages in population of $T$. urticae were $(48.7 ; 61.8$ and $69 \%)$ at average number of predator was $(19.6 ; 21.3$ and 23.4) individuals at levels of release $2 ; 4$ and 6 predator /leaf. There were significant differences between the three levels 3;6 and 9 predators. The most efficient of $C$. ornatus release (6 predators/soybean leaf) to control $T$. urticae as it produced the highest reduction percentage recording $69 \%$ of the mite pest. Statistical analysis indicated that there was high significant positive correlation between C. ornatus populations and minimum temperature 
$0.80^{* *}$ while there was non significant correlation between $C$. ornatus and maximum temperature 0.13 and relative humidity were 0.33 .

It is well known that members of the family Cheyletidae show a considerable variation in their feeding habits, including acarid mites as well as, tetranychid and tenuipalpid mites, in addition to scale insects (Carrillo et al., 2012).

The $C$. ornatus evaluated in the present study demonstrated the capacity of using this predator in biological control in soybean, since it is able to feed on T. urticae. This generalist predator will have the possibility to survive in the different phases of the culture using T. urticae as food.

Zaher et al. (1981) observed that the effect of food type on the development, feeding capacity and fecundity of $C$. ornatus (C. \& F.), a predator of scale insects and phytophagous mites, was investigated in the laboratory at $28{ }^{\circ} \mathrm{C}$ and $80 \% \mathrm{RH}$ when reared on eggs and immature stages of Tetramynychus urticae Koch.

Moraes et al.(1989) they noticed that C. ornatus, female immature stages slightly shorter than mentioned by Zaher et al.(1981). Hassan et al (2014) noticed that $C$.ornatus have a high predation capacity when fed on crawlers of scale insect Hemberlisia lataniae (Signoret); immatures of tetranychid mite Eutetranychus orientalis(Klein) and immatures of acarid mite, Tyrophagus putrescentiae (Schrank).

Mesbah and Omar (2014) reared C. ornatus on three different types of food, eggs and immatures of Raoiella indica Hirst and crawlers of Parlatoria blanchardii (Targ) at $35 \pm 2^{\circ} \mathrm{c}$ and $50 \pm 5 \%$ R.H.. The female predator had two nymphal stages, while the male had one nymphal stage. The predatory mite was noticed under date-scale insects at date-palm-trees with a high numbers. The population of predator increased following the increase of tenuipalpid mite during October to Febrauary. The results showed that high capacity of predator population growth suggests the high ability of the predator to suppress R.indica and $P$. blanchardii populations on date palms. Predation potential was greatest for larvae, followed by protonymphs, then deutonymphs. Predator consumed an average of $106.8 \& 158.2$ preys for male and female during its life span, respectively.

The statistical analysis indicated that the mean number of spider mite per soybean leaf reduced significantly in the three releasing levels compared with the control for the two predators. A. swirskii gave the highest reduction percentage on $T$. urticae followed by $C$. ornatus.

From statistical analysis of obtained data ,there were significant difference between the three levels $(2 ; 4$ and 6 predators/leaf). The most efficient level of release was 6 predator per plant to control T. urticae and reduction percentages recorded $78.9 \%$ for $A$. swirskii and $69 \%$ for $C$. ornatus. All the previous results cleared that, the efficiency of the two predators increased as well as increasing the rate of release also results indicated the possibility of controlling the two-spotted spider mite $T$. urticae on soybean crops. So, starting the release of the bio-control agents at the low level of infestation to have good control in very short time after releasing is a must.

\section{REFERENCES}

Abd Elaziz, S. M. (2016): Evalution of predacious mite Phytoseiulus persimilis Athias-Henriot to control Tetranychus urticae Koch on egg plant in sohag governorate.Acarines, 10:37-39.

Abo-Taka, S .M. ; M.A. Sweelam ; H.M. Heikal and I.A. Walash (2014):Toxicity and biological activity of five plant extracts to the two spotted spider mite, Tetranychus urticae and predatory mite, Amblyseius swirskii (Tetranychidae: Phytoseiidae).Acarines, 8(2):49-56.

Carrillo, D; J.H. Frank ; J.C. Rodrigues and J.A. Pena (2012):A review of the natural enemies of the red palm mite, Raoiellaindica (Acari: Tenuipalpidae). Experimental and Applied Acarology , 57:347-360

El-Banna A. M., M. E. El-Naggar ; S.A. Tantawy, Amira E. Mesbah, Ola M. Roshdy.(2014).Efeect of different diets on the biological aspects of Amblyseius hutu (Mesostigmata:Phytoseidae).J. Plant Protection and Pathology, vol.43,NO.2:181-190.

El-Saiedy, E.A. (2003): Integrated control of red spider mite Tetranychus urticae Koch on strawberry plants. $\mathrm{Ph}$. D. Thesis, Fac. Of Agric., Cairo Univ., 170pp.

El- Mahgoob, M. H. (2006): Studies on predacious mite inhabiting pest arthropods which infesting cucumber in green house. Ph. D. Thesis, Fac. Agric., Cairo Univ., 192 pp.

Elmoghazy, M.M.E ;E.M.A El-Saiedy and A.H.M. Romeih (2012):Integrated control of the two spotted spider mite Tetranychus urticae Koch (Acari:Tetranychidae) on faba bean Vicia faba L. in an open field at Behaira Governorate, Egypt. International Jor. of environmental science and engineering ,2:93-100.

Hassan, M.F; M. E. El-Naggar ; Amira E. Mesbah and R. A. El-Nahas (2014):Biological aspects and life table parameters of Cheletogenes ornatus (Canestrini \&Fanzago)(Acari:Cheyletidae) When fed on different types of food and temperatures. Jornal of Egyptian Society of Acarology. Vol,(8 )No,(2);31-35

Henderson, C.F. and E.W. Tilton (1955):Tests with acaricides against the brown wheat mite,J.Econ.Entomol., 48:157-161

Hoy M.A.(2013): Assesment of Hemicheyltia wellsina (Acari:Cheyletidae) as apotintial predator for biological control of arthropod pests on orchids. Entomological Society of America.301-731.

Ibrahim, G. A., Abd El-Wahed, N. M. and Halawa, A. M. (2005): Bilogical control of the two spotted spider mite Tetranychus urticae Koch using the phytoseiid mite, Neoseiulus cucumeris (Oudemans) on cucumber (Acari: Tetranychidae: Phytoseiidae). Egypt J. Agric.Res., 84 (4).

Ibrahim, G. A. ;A.M. Metwally ; A.S.H. El-Halawany and K.M. El-Sayed (2010):Evaluting the efficiency of different levels of Neoseiulus californicus (McGregor) released for controlling the spider mite Tetranychus urticae Koch and European red mite Panonychus ulmi Koch on young apple trees. Egypt J. Agric.Res., 88 (2):451-463. 
Mesbah Amira E. (2014):Mites inhabiting date palm trees and their dynamics with reference to reproduction and life table parameters of Raoiella indica Hirst (Tenuipalpidae) at three different temperatures. Jornal of Egyptian Society of Acarology. Vol,(8)No,(2).

Mesbah, Amira E. and N.A. Omar (2014):Predatorprey preferences and Life-Table-Parameters of Cheletogenes ornatus (Canestrini\&Fanzago)to red palm mite Raoiella indicaHirst and datescale-insect Parlatoria blanchardii (Targ.) (Acari:Cheyletidae:Tenuipalpidae).Journal of Egyptian Society of Acarology.8(1):19-23.

Melgarejo, L., J.M. Ferraz and G.B. Fernandes (2013): Transgênicos no Brasil. Agriculturas, 10, 14-21.

Mowafi, M.H. (2005): Release of the predaceious mite, Phytoseiulus macropils Banks to control Tetranychus urticae Koch (Acari:Phytoseiidae: Tetranychidae) in cucumber green house. Egypt Jor. of Biological Pest Control,15 (2):109-111.

Moraes,G.J.D; R.S. Neto and H.C.S. Pinto (1989): Morphology, biology and pesticide tolerance of Chelotogenes ornatus [Acari: Cheyletidae]. Volume 34, Issue 4, pp 477-484.

Nicholls, C.I. and M.A. Altieri (2005): Designing and implementing a habitat management strategy to enhance biological pest control in agroecosystems. Biodynamics, 26-36.

Reichert, M.B.; G.L. Silva; M.S. Rocha; L. Johann and N.J. Ferla (2014): Mite fauna (Acari) in soybean agroecosystem in the northwestern region of Rio Grande do Sul State, Brazil. Syst Appl Acarol, vol. 19, no. 2, pp. 123-136.
Rezende, J.M., A.C. Lofego ;F.M. Nuvoloni and D. Navia (2014): Mites from Cerrado fragments and adjacent soybean crops: does the native vegetation help or harm the plantation? Experimental \& Applied Acarology, vol. 64, no. 4, pp. 501-518.

SAS Institute. (2010). SAS Statistics and Graphics Guide, Release 9.1. SAS Institute, Cary, North Carolina, 27513, USA.

Tirello, P. ; A. Pozzebon ; S. Cassanelli ; T VanLeeuwen and C. Duso (2012): Resistance to acaricides in Italian strains of Tetranychus urticae: Toxicological and enzymatic assays. Exp. Appl. Acarol.,57:53-64.

Van-Leeuwen, T.;S. Van Pottelbrge ;R. Nauen and L. Tirry: (2007):Organophosphate insecticides and acaricides antagonize bife-nazate toxicity through esterase inhibition in Tetranychus urticae. Pest Manag.Sci..,63:1172-1177.

Oatman, E. R., J. A. McMurtry, F. E. Gilstrap, and V. Voth. (1977): Effect of Releases of Amblyseius californicus on the Twospotted Spider Mite on Strawberry in Southern California. Jor. Econ. Entomo1.70,5:638-641.

Waheeb , M.I.A (2016):Field evalution of two pesticides and apredatory mite release in controlling red spider mite infesting Soybean and Cotton plants.Acarines, 10:59-63.

Zaher, M. A., Yousef, A. E. A. \&Kandil, M. M.(1981): Effect of food on the biology of Cheletogenes ornatus (C.\&F.) [Acari: Prostigmata: Cheyletidae]. Acarologia, 22,4; 361-366.

\section{كفاءة الأطلاق المبكر للمفترسان الأكاروسيان ول Amblyseius swirskii

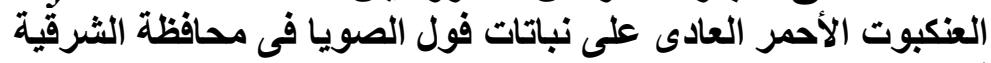

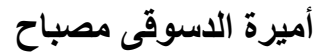 معهد بحوث وقاية النباتاتـ مركز البحوث الزراعية ـ الدقى ـ مصر}

Amblyseius swirskii (Athias-Henriot) and Cheletogenes ornatus تم تقييم كفاءة المفترسان الأكاروسيان (Canestrini \& Fanzago)

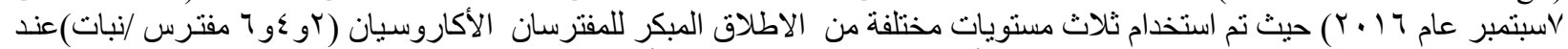

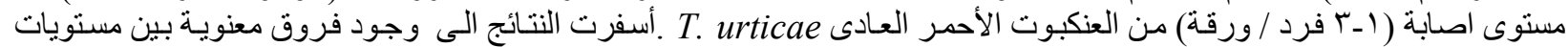

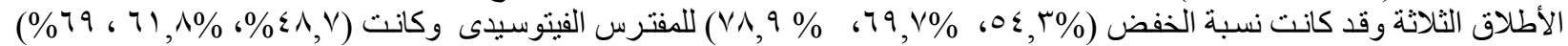

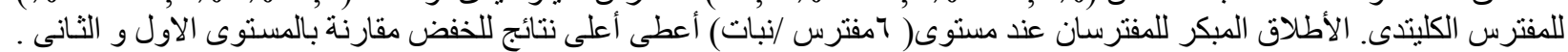

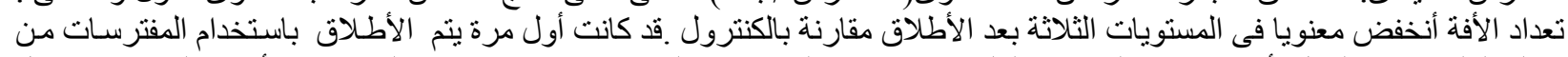

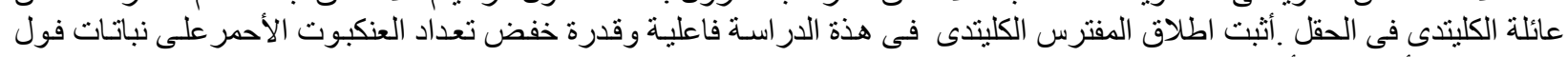

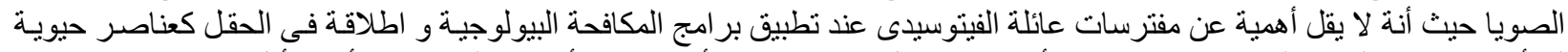

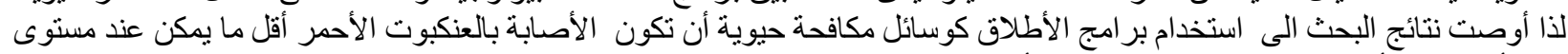

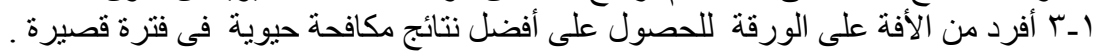

